\title{
Estimation of body composition of pigs by a near-infrared interactance probe technique*
}

\begin{abstract}
Near-infrared (NIR) interactance was evaluated as a potentially new method for estimating live body and carcass composition of pigs. Using a surface placed fiber optic probe, measurements of the live animal and carcass were made on a total of 120 pigs. These measurements were compared with lipid and protein content of soft tissue dissected from the pig carcass. NIR results were evaluated using multiple regression equations containing NIR readings at various locations on the body, combinations of wavelengths and with or without ultrasonic fat depth readings and body weight. NIR measurements made on the carcass predicted percent carcass fat $(\mathrm{R}=0.71)$ better than did measurements made on the live animal $(\mathrm{R}=0.66)$, however, both could be improved substantially by including live body weight in the prediction equation $(\mathrm{R}=0.93$ and 0.91$)$. Spectral information indicated that the depth of tissue penetration and reflectance may be the primary limitation in this application of the current technology.
\end{abstract}

Key Words: NIR, near-infrared, body composition, pigs

\section{Zusammenfassung}

Titel der Arbeit: Schätzung der Körperzusammensetzung beim Schwein mittels Nahinfrarot-Interaktanz

Die Verwendbarkeit der Nahinfrarot-Interaktanz (NIR) wurde als potentielle Technik zur Schätzung der In-vivound Schlachtkörperzusammensetzung beim Schwein untersucht. Mit Hilfe einer faser-optischen Oberflächensonde wurden an insgesamt 120 Tieren Messungen in vivo und am Schlachtkörper durchgeführt. Die Messdaten wurden mit dem Lipid- und Proteingehalt des knochenfreien Gewebes der korrespondierenden Schweineschlachtkörper verglichen. Eine multiple Regressionsanalyse diente zur Evaluierung der Schätzgenauigkeit von NIR. In die Regressionsgleichungen gingen NIR-Daten von verschiedenen Körper-Messpositionen, Kombinationen verschiedener Wellenlängen sowohl unter Verwendung als auch ohne Verwendung von zusätzlichen Ultraschall-Speckdicken bzw. der Körpermasse ein. NIR-Messungen am Schlachtkörper schätzten den Fettgehalt (\%) im Schlachtkörper mit $\mathrm{R}=0,71$ besser als am lebenden Tier mit $\mathrm{R}=0,66$. Unter Berücksichtigung der Körpermasse in der Regressionsgleichung ergab sich eine wesentliche Verbesserung der Schätzgenauigkeit mit R=0,93 bzw. 0,91.

Gemäß der Informationen aus den Nahinfrarot-Spektren liegen die hauptsächlichen Begrenzungsfaktoren für die Nutzung der angewandten Technik in der Tiefe der Gewebedurchdringung sowie in Reflektionsartefakten.

Schlüsselwörter: NIR, Nahinfrarot-Interaktanz, Körperzusammensetzung, Schwein

\section{Introduction}

Compositional analysis by near-infrared (NIR) spectroscopy is based on the detection of definitive transmission or reflectance characteristics of radiation in the 850 to 2600 $\mathrm{nm}$ region by the major components (i.e., water, fat or protein) of the sample in question. NIR is widely used to predict the composition or quality of various plant materials (NORRIS, 1983). This technique has also been studied as a method for compositional analysis of homogeneous samples of animal tissues (KRUGGEL et al., 1981; LANZA, 1983) or whole-carcass composition of homogeneously prepared 
mouse (EISEN et al., 1984) or chicken (RENDEN et al., 1986) carcasses. SLAUGHTER et al. (1989) used near infrared reflectance to measure the fat and protein content of samples of ground hog carcasses. There has been considerable interest in the application of NIR spectroscopy for evaluating the quality of beef (PARK et al., 1998; BYRNE et al., 1998; RØDBOTTEN et al., 2000) and pork (BRØNDUM et al., 2000; GEESINK et al., 2003; HOVING-BOLINK et al., 2005). IRIE (1999) evaluated different types of fiber optic probes (surface, contact, insertion or transmittance) for NIR spectroscopic evaluation of pork fat quality. The potential of on-line application of NIR reflectance spectroscopy has been studied for measuring the tenderness of beef longissimus muscle (SHACKELFORD et al., 2005) and for the determination of fatty acid composition of intramuscular fat of pork loin (GONZÁLEZ-MARTÍN et al., 2005). CONWAY et al. (1984) evaluated infrared interactance as a means of estimating body composition in human subjects. The latter approach utilized a fiber optic probe with multiple site measurements on the body. Likewise, SHIMAMOTO et al. (2004) measured the fat content of frozen and thawed mackerel by near infrared spectroscopy using a fiber optic probe in the interactance mode. From these studies it appears that NIR offers a potentially rapid, noninvasive technique for estimation of body composition.

\section{Materials and Methods}

In two separate experiments NIR measurements and carcass analysis were performed when pigs attained live weights of approximately 30, 60 or $90 \mathrm{~kg}$ (20 pigs per weight group in each experiment, 120 pigs total). All pigs used in this study were YorkshireDuroc crosses. Starting at eight weeks of age, differences in carcass composition were enhanced by feeding half the pigs in each group a $12 \%$ protein diet and the other half a $24 \%$ protein diet. Carcass composition was determined by analysis of the soft tissue dissected from the left-half of the eviscerated carcass for lipid and protein content (MITCHELL and STEELE, 1987). The dissected soft tissue (mostly muscle and fat) was twice ground through a whole-body grinder fitted with a .32-cm sieve. A .5-kg sample was used for protein and lipid analysis. Protein content of carcass was measured on triplicate 2- to 3-g samples by the Kjeldahl procedure. Lipid analysis was performed on triplicate 5- to 7-g samples by the procedure of FOLCH et al. (1957).

NIR readings on the live animal were made at three locations along the left side of the pig. One reading (side) was taken half-way up the side at the mid-point between the front and hind legs. The other two readings (shoulder and ham) were made the same distance from the top of the back as the side reading, but were centered, front to rear, on either the shoulder or ham. At each site the hair was shaved to facilitate placing the fiber optic probe directly on the skin. Carcass readings were taken at the same three locations within one hour of the time of slaughter. The slaughter procedure involved removal of hair and the outer pigmented layer of skin. These studies were conducted in accordance with protocols approved by the USDA-ARS, Beltsville Animal Care and Use committee.

The NIR instrument used in Experiment 1 was a Futrex (Futrex Inc., Gaithersburg, MD) prototype model equipped with a fiber optic probe. The fiber optic probe served to conduct radiation from the light source to the site on the animal and collect the interacted radiation and conduct it back to the detector. The fiber optic probe is similar to the contact probe described by IRIE (1999). The instrument was set to monitor three 
wavelengths: 890, 930 and $940 \mathrm{~nm}$. The interactance (I) was measured at each wavelength and displayed $\log (1 / \mathrm{I})$ or as an instrument computed reading for $\%$ fat.

In the second experiment a Futrex model F-100 was used. This was a slight modification of the instrument as used in Experiment 1. The three filter settings in this instrument were: 898, 940 and $950 \mathrm{~nm}$ with 75, 40 and $40 \mathrm{~nm}$ half-power band-widths, respectively. Also, in Experiment 2 the depth of subcutaneous fat at each site on the live animal was estimated using an ultrasonic probe (Scanoprobe II, Model 731C, Ithaco Inc, Ithaca, NY).

For spectral measurements, an approximately $10 \mathrm{~cm}$ thick section of tissue was dissected from the ham area of a pig carcass. The tissue was then dissected into separate layers of skin, fat and muscle. Spectral measurements were made on these sections separately or with varying thicknesses and combinations of fat and muscle underlying the skin. The spectrometer used for these measurements was as described by NORRIS (1983), interfaced with a fiber optic probe.

Samples of subcutaneous adipose tissue (1-3 g) were taken from the back of each carcass (center of the carcass and $65 \mathrm{~mm}$ from midline) in this study. Each sample was analyzed for lipid content by the same procedure as detailed above for ground carcass samples. This information was included in a data set containing adipose tissue lipid content measurements from 239 other pigs of the same genotype and dietary background. In addition to the 30,60, and $90 \mathrm{~kg}$ weights, this group also included 20 piglets weighing $8 \mathrm{~kg}$.

Depending on experiment I or II, the NIR measurements were fitted to various models comparing different multiple regression equations to determine the best combination of sites (shoulder, side, or ham) with corresponding interactance readings at different NIR wavelength settings, NIR fat\% (only experiment I), ultrasound fat depth (only experiment II) and additionally body weight to predict percent lipid (fat) in the whole body (NORRIS et al., 1976). Multiple correlation coefficients (R) and standard error of the estimates (SE) for prediction of carcass composition were computed using Statgraphics Plus (ver. 5.1).

The general model including all variables measured in the multiple regression equation is:

$\mathbf{Y}_{\mathbf{i}}=\beta_{0}+\beta_{1} \mathbf{X}_{1, \mathrm{i}}+\beta_{2} \mathbf{X}_{2, \mathrm{i}}+\ldots \ldots \ldots+\beta_{\mathrm{k}} \mathbf{X}_{\mathrm{k}, \mathrm{i}}+\varepsilon_{\mathrm{t}}$,

with

$\mathrm{Y}_{\mathrm{i}}=$ dependent variable (percent lipid or percent protein in the whole body),

$\beta_{0}-\beta_{\mathrm{k}}=$ constants ( $\beta_{0}$ - intercept; $\beta_{1}-\beta_{\mathrm{k}}$ - slopes),

$\mathrm{X}_{1, \mathrm{i}}-\mathrm{X}_{\mathrm{k}, \mathrm{i}}{ }^{*}=$ independent (explanatory) variables (interactance readings at different NIR settings, NIR fat\%, ultrasound fat depth -- at different sites respectively, and body weight),

$\varepsilon_{\mathrm{t}}=$ error.

*The variables selected to be included in the different (multiple) regression equations are shown in tables 1-4. Only the variable combinations in the regression equations with the highest (multiple) correlation coefficients will be shown in tables 1-4.

Differences in carcass composition due to body size or diet were evaluated by analysis of variance followed by a multiple range test based on Fisher's least significant difference (95\% LSD) procedure.

\section{Results}

The mean carcass lipid content for all pigs in this study was $25.1 \%$. The main source of variation in lipid content was size of the pig. At $8 \mathrm{~kg}$ the mean lipid content was 
$4.6 \%$, at $30 \mathrm{~kg}$ it was $18.7 \%$, at $60 \mathrm{~kg}$ it was $25.2 \%$, and at $90 \mathrm{~kg}$ it was $31.7 \%$ ( $\mathrm{P}<$ $0.001)$. The protein level in the diet resulted in a further divergence in carcass composition. For pigs fed the $24 \%$ protein diet the mean carcass lipid content was $21.2 \%$, while for pigs fed the $12 \%$ protein diet it was $29.1 \%(\mathrm{P}<0.001)$.

The spectra of $\log (1 / \mathrm{I})$ in the 700 to $1100 \mathrm{~nm}$ region for skin, muscle, fat and a reconstructed composite from the pig is shown in Figure 1. The peak at $930 \mathrm{~nm}$, which predominates on the fat spectrum, corresponds to that reported for fat, while peaks in the 970 to $980 \mathrm{~nm}$ region for the other tissues correspond to that reported for water (CONWAY et al., 1984). Sectioning and reconstruction of the tissues in layers of varying thickness indicated that change in composition could be detected to a depth of approximately one $\mathrm{cm}$. Thus, the spectrum for the tissue composite appears to be influenced predominately by the composition of the skin layer and to a lesser extent by that of the fat and muscle layers.

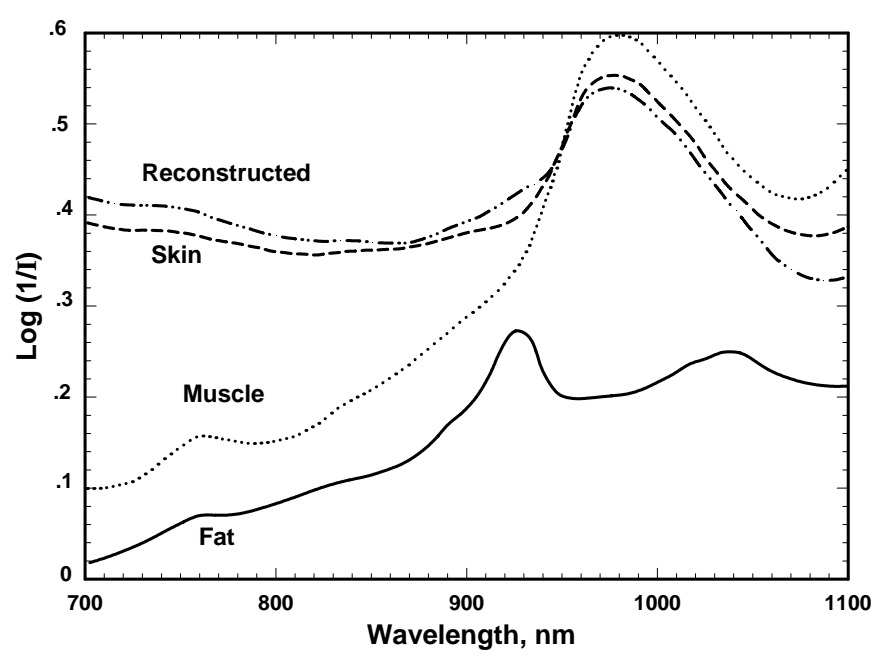

Fig. 1: NIR spectrum of dissected and reconstructed pig tissues. [NIR-Spektrum von Schweinegeweben (getrennt und wieder zusammengesetzt)]

From Experiment 1 there was no clear indication that NIR readings taken at any one or a combination of the three sites on the animal provided a better measurement for predicting percent fat in the carcass, although correlation coefficients with readings from the ham were slightly higher. Using various combinations of readings from the ham of the carcass in multiple regression equations resulted in higher correlation coefficients than when the readings were made on the live animal (Table 1). Either could be improved substantially by including live body weight in the equation.

In Experiment 2 (Table 2), a combination of readings from the ham and shoulder of the carcass gave results similar to experiment $1(\mathrm{R}=0.71)$, where $\mathrm{R}$ is the coefficient of multiple correlation. There was, however, an improvement for readings taken on the live animal ( $\mathrm{R}=0.35$ vs. 0.66 for Experiments 1 and 2 respectively). Inclusion of either live weight or ultrasonic probe measurements of the subcutaneous fat depth at the various sites as terms in multiple regression equations improved the prediction of carcass fat. Ultrasonic probe measurements alone gave higher correlations with percent carcass fat than that of NIR measurements alone. Live weight terms slightly improved the use of ultrasonic probe measurements, however, live weight plus ultrasonic fat depth was no better than NIR plus live weight or NIR plus the ultrasonic measurement. 
Table 1

Multiple correlation coefficients (R) and standard error of the estimates (SE) for prediction of carcass lipid (as percentage of live body weight) using NIR and live weight measurements: Experiment 1 [Multiple Korrelationskoeffizienten (R) und Standardschätzfehler (SE) für die Schätzung des Schlachtkörperfettgehaltes (in \% der Lebendmasse) unter Verwendung von NIR- und Lebendmassemessungen: Experiment 1]

\begin{tabular}{lll}
\hline Measurement & $\mathrm{R}$ & $\mathrm{SE}$ \\
\hline NIR-Carcass (ham) & & 5.0 \\
A: (890/930, 890/940, 930/940) & & 4.8 \\
B: A + \% reading & 0.71 & 4.1 \\
C: A + live weight & 0.74 & 4.1 \\
D: B + live weight & 0.82 & 6.7 \\
NIR-Live (ham) & 0.82 & 5.8 \\
A & & 3.9 \\
B & 0.35 & 3.9 \\
C & 0.59 & 0.84 \\
\hline
\end{tabular}

${ }^{a}$ NIR readings were based on the ratio of measurements made at the wavelengths (nm) indicated.

Table 2

Multiple correlation coefficients (R) and standard error of the estimates (SE) for prediction of carcass lipid (percentage of live body weight) using NIR and/or ultrasonic probe and live weight: Experiment 2 [Multiple Korrelationskoeffizienten (R) und Standardschätzfehler (SE) für die Schätzung des Schlachtkörperfettgehaltes (in \% der Lebendmasse) unter Verwendung von NIR- und/oder Ultraschall- sowie Lebendmassemessungen: Experiment 2]

\begin{tabular}{|c|c|c|}
\hline Measurements & $\mathrm{R}$ & SE \\
\hline NIR-Carcass $(1,3)^{\mathrm{a}}$ & 0.705 & 5.284 \\
\hline $\begin{array}{l}+ \text { Ultrasonic }(2)^{\mathrm{b}} \\
+ \text { Ultrasonic }(1,2) \\
+ \text { Ultrasonic }(1,2,3) \\
+ \text { Live weight }\end{array}$ & $\begin{array}{l}0.925 \\
0.929 \\
0.929 \\
0.930\end{array}$ & $\begin{array}{l}2.852 \\
2.812 \\
2.837 \\
2.770\end{array}$ \\
\hline $\begin{aligned} \text { NIR-Live }(1,2)^{\mathrm{C}} & \\
& + \text { Ultrasonic }(2) \\
& + \text { Ultrasonic }(1,2) \\
& + \text { Ultrasonic }(1,2,3) \\
& + \text { Live weight }\end{aligned}$ & $\begin{array}{l}0.656 \\
0.922 \\
0.928 \\
0.929 \\
0.905\end{array}$ & $\begin{array}{l}5.639 \\
2.906 \\
2.826 \\
2.846 \\
3.202\end{array}$ \\
\hline + Live weight & $\begin{array}{l}0.821 \\
0.880\end{array}$ & $\begin{array}{l}4.142 \\
3.477\end{array}$ \\
\hline + Live weight & $\begin{array}{l}0.888 \\
0.889\end{array}$ & $\begin{array}{l}3.332 \\
3.359\end{array}$ \\
\hline + Live weight & $\begin{array}{l}0.794 \\
0.859\end{array}$ & $\begin{array}{l}4.409 \\
3.748\end{array}$ \\
\hline $\begin{array}{l}\text { Ultrasonic }(1,2,3) \\
+ \text { Live weight }\end{array}$ & $\begin{array}{l}0.902 \\
0.903\end{array}$ & $\begin{array}{l}3.182 \\
3.200\end{array}$ \\
\hline
\end{tabular}

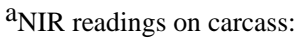

(1) two readings from ham; $940 \mathrm{~nm} / 950 \mathrm{~nm}, 940 \mathrm{~nm} / 898 \mathrm{~nm}$

(3) two readings from shoulder; $898 \mathrm{~nm} / 940 \mathrm{~nm}, 950 \mathrm{~nm} / 940 \mathrm{~nm}$.

bUltrasonic probe measurements (subcutaneaous fat depth) at (1) ham, (2) side and (3) shoulder of the live animal.

${ }^{\mathrm{C}} \mathrm{NIR}$ readings on live animal:

(1) two readings from ham; $950 \mathrm{~nm} / 898 \mathrm{~nm}, 898 \mathrm{~nm} / 940 \mathrm{~nm}$

(2) two readings from side; $940 \mathrm{~nm} / 950 \mathrm{~nm}, 898 \mathrm{~nm} / 950 \mathrm{~nm}$.
}

In Table 3 the correlations for NIR and carcass lipid (corrected for water content of carcass adipose tissue) are similar to that of adipose tissue shown in Table 2. The relationship between carcass lipid and that predicted by two NIR measurements (consisting of four ratios) on the carcass plus live body weight is depicted in Figure 2. 
Table 3

Multiple correlation coefficients (R) and standard error of the estimates (SE) for prediction of carcass lipid or protein (percentage of live body weight) using NIR alone or with ultrasonic or live weight measurements: Experiment 2 [Multiple Korrelationskoeffizienten (R) und Standardschätzfehler (SE) für die Schätzung des Schlachtkörperlipid- bzw. -proteingehaltes (in \% der Lebendmasse) unter alleiniger Verwendung von NIR oder unter Einbeziehung von Ultraschall- bzw. Lebendmassemessungen: Experiment 2]

\begin{tabular}{|c|c|c|c|c|}
\hline \multirow[t]{2}{*}{ Measurements } & \multicolumn{2}{|c|}{ Lipid } & \multicolumn{2}{|c|}{ Protein } \\
\hline & $\mathrm{R}$ & $\mathrm{SE}$ & $\mathrm{R}$ & SE \\
\hline NIR-Carcass $(1,3)^{\mathrm{a}}$ & 0.709 & 4.985 & 0.532 & 0.973 \\
\hline $\begin{array}{l}+ \text { Ultrasonic }(2)^{\mathrm{b}} \\
+ \text { Ultrasonic }(1,2) \\
+ \text { Ultrasonic }(1,2,3) \\
+ \text { Live weight }\end{array}$ & $\begin{array}{l}0.935 \\
0.937 \\
0.938 \\
0.941\end{array}$ & $\begin{array}{l}2.531 \\
2.512 \\
2.529 \\
2.419\end{array}$ & $\begin{array}{l}0.656 \\
0.656 \\
0.663 \\
0.686\end{array}$ & $\begin{array}{l}0.875 \\
0.884 \\
0.885 \\
0.843\end{array}$ \\
\hline $\begin{aligned} \text { NIR-Live }(1,2)^{\mathrm{C}} & \\
& + \text { Ultrasonic }(2) \\
& + \text { Ultrasonic }(1,2) \\
& + \text { Ultrasonic }(1,2,3) \\
& + \text { Live weight }\end{aligned}$ & $\begin{array}{l}0.654 \\
0.932 \\
0.936 \\
0.937 \\
0.913\end{array}$ & $\begin{array}{l}5.350 \\
2.590 \\
2.534 \\
2.538 \\
2.905\end{array}$ & $\begin{array}{l}0.512 \\
0.675 \\
0.676 \\
0.691 \\
0.723\end{array}$ & $\begin{array}{l}0.987 \\
0.856 \\
0.862 \\
0.854 \\
0.801\end{array}$ \\
\hline
\end{tabular}

a NIR readings on carcass:

(1) two readings from ham; $940 \mathrm{~nm} / 950 \mathrm{~nm}, 898 \mathrm{~nm} / 950 \mathrm{~nm}$

(3) two readings from shoulder; $950 \mathrm{~nm} / 940 \mathrm{~nm}, 898 \mathrm{~nm} / 940 \mathrm{~nm}$.

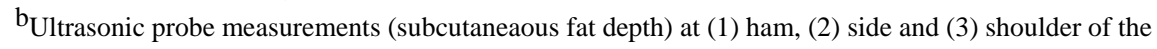
live animal.

${ }^{\mathrm{C}}$ NIR readings on live animal:

(1) two readings from ham; $950 \mathrm{~nm} / 898 \mathrm{~nm}, 898 \mathrm{~nm} / 940 \mathrm{~nm}$

(2) two readings from side; $940 \mathrm{~nm} / 950 \mathrm{~nm}, 898 \mathrm{~nm} / 950 \mathrm{~nm}$.

Table 3 also includes correlations for the same measurements and carcass protein. The correlations between NIR and carcass protein were lower than for carcass fat and were improved to a lesser extent by inclusion of ultrasonic or live weight measurements in the multiterm equations. In Figure 3, NIR readings (four ratios) from two sites on the live animal and live body weight were used to predict percent lipid in the carcass.

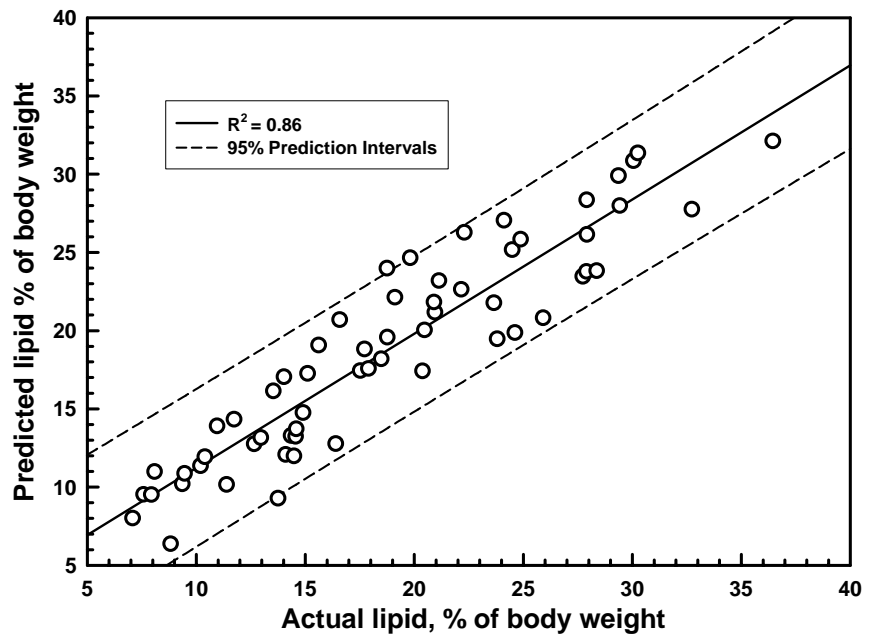

Fig. 2: Prediction of lipid content (\% of live body weight) by NIR measurements at two locations on the carcass plus live body weight. The NIR readings consisted of two readings from the ham $(940 \mathrm{~nm} / 950 \mathrm{~nm}$ and 940nm/898nm) and two readings from the shoulder $(898 \mathrm{~nm} / 940 \mathrm{~nm}$ and $950 \mathrm{~nm} / 940 \mathrm{~nm}$ ) [Schätzung des Fettgehaltes (in \% der Lebendmasse) mittels NIR-Messdaten von zwei Positionen am Schlachtkörper plus Lebendmasse. Die NIR-Daten bestanden aus jeweils zwei Messreihen am Schinken (940nm/950nm und 940nm/898nm) und an der Schulter (898nm/940nm und 950nm/940nm)] 


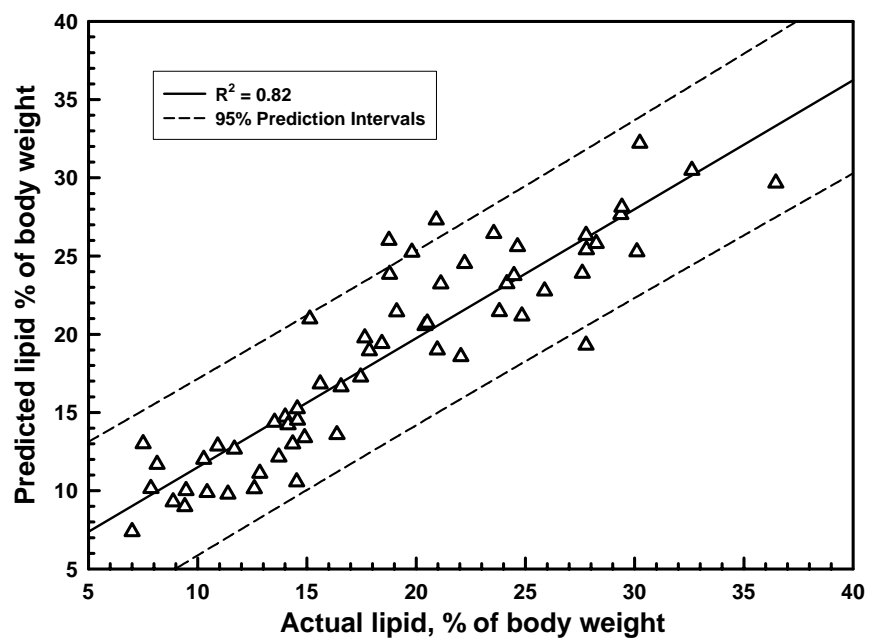

Fig. 3: Prediction of lipid content (\% of live body weight) by NIR measurements at two locations on the live animal plus live body weight. The NIR readings consisted of two readings from the ham $(950 \mathrm{~nm} / 898 \mathrm{~nm}$ and 898nm/940nm) and two from the side $(940 \mathrm{~nm} / 950 \mathrm{~nm}$ and $898 \mathrm{~nm} / 950 \mathrm{~nm}$ ) [Schätzung des Fettgehaltes (in \% der Lebendmasse) mittels NIR-Messdaten von zwei Positionen am lebenden Tier plus Lebendmasse. Die NIR-Daten bestanden aus jeweils zwei Messreihen am Schinken $(940 \mathrm{~nm} / 950 \mathrm{~nm}$ and $940 \mathrm{~nm} / 898 \mathrm{~nm})$ und an der Schulter (898nm/940nm and $950 \mathrm{~nm} / 940 \mathrm{~nm})]$

In Table 4 the same measurements as shown in Table 3 were used to predict lipid and protein as percent of the dissected soft tissue. Using these values, prediction of percent lipid based on NIR measurements alone were improved slightly ( $\mathrm{R}=0.71 \mathrm{vs.} 0.75$ for carcass NIR and $\mathrm{R}=0.65 \mathrm{vs}$. 0.73 for live NIR). The improvement was more dramatic for the prediction of percent protein, in fact, with values as percent in the dissected soft tissue the correlation coefficients were the same for lipid and protein.

Table 4

Multiple correlation coefficients (R) and standard error of the estimates (SE) for prediction of carcass lipid and protein (percentage in dissected soft tissue) using NIR alone or with ultrasonic or live weight measurements: Experiment 2 [Multiple Korrelationskoeffizienten (R) und Standardschätzfehler (SE) für die Schätzung des Schlachtkörperlipid- bzw. -proteingehaltes (in \% der knochen- und innereienfreien Schlachtkörpermasse) unter alleiniger Verwendung von NIR oder unter Einbeziehung von Ultraschall- oder Lebendmassemessungen: Experiment 2]

\begin{tabular}{|c|c|c|c|c|}
\hline \multirow{2}{*}{ Measurements } & \multicolumn{2}{|c|}{ Lipid } & \multicolumn{2}{|c|}{ Protein } \\
\hline & $\mathrm{R}$ & SE & $\mathrm{R}$ & SE \\
\hline NIR-Carcass $(1,3)^{\mathrm{a}}$ & 0.752 & 6.471 & 0.753 & 1.749 \\
\hline $\begin{array}{l}\text { + Ultrasonic }(2)^{\mathrm{b}} \\
+ \text { Ultrasonic }(1,2) \\
+ \text { Ultrasonic }(1,2,3) \\
\text { + Live weight }\end{array}$ & $\begin{array}{l}0.894 \\
0.895 \\
0.896 \\
0.891\end{array}$ & $\begin{array}{l}4.436 \\
4.467 \\
4.484 \\
4.504\end{array}$ & $\begin{array}{l}0.832 \\
0.832 \\
0.837 \\
0.841\end{array}$ & $\begin{array}{l}1.490 \\
1.500 \\
1.495 \\
1.449\end{array}$ \\
\hline $\begin{aligned} \text { NIR-Live }(1,2)^{\mathrm{C}} & \\
& + \text { Ultrasonic }(2) \\
& + \text { Ultrasonic }(1,2) \\
& + \text { Ultrasonic }(1,2,3) \\
& + \text { Live weight }\end{aligned}$ & $\begin{array}{l}0.728 \\
0.901 \\
0.903 \\
0.907 \\
0.877\end{array}$ & $\begin{array}{l}6.727 \\
4.287 \\
4.290 \\
4.243 \\
4.767\end{array}$ & $\begin{array}{l}0.730 \\
0.826 \\
0.827 \\
0.835 \\
0.822\end{array}$ & $\begin{array}{l}1.817 \\
1.511 \\
1.520 \\
1.504 \\
1.528\end{array}$ \\
\hline
\end{tabular}

$\mathrm{a}_{\mathrm{NIR}}$ readings on carcass:

(1) two readings from ham; $940 \mathrm{~nm} / 950 \mathrm{~nm}, 898 \mathrm{~nm} / 950 \mathrm{~nm}$

(3) two readings from shoulder; $950 \mathrm{~nm} / 940 \mathrm{~nm}, 898 \mathrm{~nm} / 940 \mathrm{~nm}$.

bUltrasonic probe measurements (subcutaneaous fat depth) at (1) ham, (2) side and (3) shoulder of the live animal.

${ }^{\mathrm{c}}$ NIR readings on live animal:

(1) two readings from ham; $950 \mathrm{~nm} / 898 \mathrm{~nm}, 898 \mathrm{~nm} / 940 \mathrm{~nm}$

(2) two readings from side; $940 \mathrm{~nm} / 950 \mathrm{~nm}, 898 \mathrm{~nm} / 950 \mathrm{~nm}$. 
The results for the chemical determination of the lipid content of subcutaneous adipose tissue samples obtained from 359 pigs (120 pigs from the NIR experiments plus 239 pigs of the same genotype and dietary background) is presented in Figure 4. The correlation (r) between the percent lipid in the adipose tissue and the Log of the percent lipid in the carcass was 0.84 .

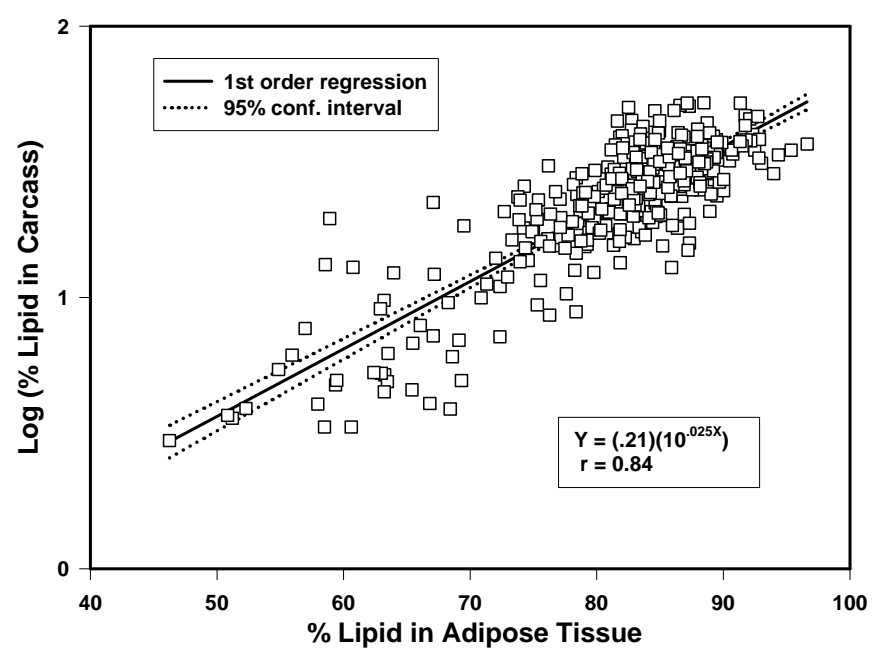

Fig. 4: Relationship between the percent lipid in the adipose tissue and the Log of the percent lipid in the whole carcass $(n=359)$ [Beziehung zwischen dem Lipidgehalt (\%) im Fettgewebe und dem Logarithmus von Lipid (\%) im gesamten Schlachtkörper $(\mathrm{n}=359)]$

\section{Discussion}

NIR has received considerable attention as a possible technique for predicting the body composition of humans. In the initial study involving adult females, CONWAY et al. (1984) reported correlation coefficients (r) of 0.94, 0.90 and 0.89 when NIR alone was compared with deuterium oxide dilution, skinfold and ultrasound measurements. However, subsequent studies have either suggested the method to be invalid (ISRAEL et al., 1989; ELIA et al., 1990; HEYWARD et al., 1992; MCLEAN and SKINNER 1992; EATON et al., 1993; WILMORE et al., 1994) or that the instrument manufacturer's prediction equation needed refinement (HADDOCK et al., 1990; KLIMIS-TAVANTZIS et al., 1992; NIELSEN et al., 1992). In general, the correlation between NIR and other body composition measurements in humans have been higher than observed in the present study with pigs. However, it should be noted that most of those studies used prediction equations provided by the instrument manufacturer, which in some cases included body weight. In this study NIR alone gave correlation coefficients of no better than about 0.75 . Although the estimation with the pig could be improved by including live body weight in the equation, NIR alone is a better indicator of the value of the method.

Three factors that may have contributed to the better response with humans are: (1) better defined anatomical sites for making the measurements, (2) humans have much thinner skin than the pig and (3) in most cases the human has less subcutaneous fat. With applications of this type, in order for a probe technique to be valid the sample must either be homogenous or the location or combination of locations analyzed must be representative of the total and, in the case of animals, this relationship must be maintained throughout growth and development, encompassing a wide range in body composition. With the human such anthropometric measurements are commonly used 
and tested. The only analogous measurements with the pig are on the back where fat depth and loineye area are commonly measured, but where the fat depth precluded NIR measurements of anything but skin and subcutaneous fat. Human studies reported by WILSON and HEYWARD (1992) and WILMORE et al., (1994) indicated that only the NIR reading from the biceps contributed significantly to the variance in percent body fat as measured by hydrostatic weighing. Several other studies (CONWAY et al., 1984; HORTOBAGYI et al., 1991; MCLEAN and SKINNER, 1992; QUATROCHI et al., 1992; EATON et al., 1993) have reported that the inclusion of multiple site readings did not improve NIR results. The study by WILSON and HEYWARD (1992) found that the NIR results systematically overestimated percent body fat in subjects with less than $20.7 \%$ body fat and underestimated percent body fat in subjects with more than $20.7 \%$ body fat. Studies by ELIA et al., (1990), HADDOCK et al., (1990), HEYWARD et al., (1992), MCLEAN and SKINNER (1992), FRANSILLA-KALLUNKI (1992), EATON et al., (1993) and WILMORE et al., (1994) also reported that NIR underestimated percent body fat in obese subjects.

In the study with mackerel (SHIMAMOTO et al., 2004), NIR measurements were highly correlated to the fat content of the dissected fillet. Measurements taken at a single location and compared to the fat content determined by chemical analysis resulted in multiple correlation coefficients (based on four selected wavelengths) of 0.95 and 0.97 for frozen and thawed fish, respectively.

Figure 1 gives an indication that skin thickness may present a problem with NIR measurements on pigs. Spectra obtained with human subjects (CONWAY et al., 1984) showed a similar spectrum for fat (major peak at $930 \mathrm{~nm}$ ) with noticeable differences in response between lean and fatter individuals. Likewise, IRIE (1999) observed a major peak at $930 \mathrm{~nm}$ when the contact probe was placed directly on dissected pork fat. However, with the sample obtained from the pig (Figure 1), when the fat layer was placed beneath the skin only a slight response was observable at $930 \mathrm{~nm}$.

The three sites chosen for NIR measurement on the pig represent the major muscle mass of the pig at locations not subject to excessive fat covering. Ultrasonic information obtained at the three weights indicated that at $30 \mathrm{~kg}$ live body weight fat depths (including skin) at all three sites were generally less than one $\mathrm{cm}$. Beginning at $60 \mathrm{~kg}$, one or more of the sites frequently showed one cm or more fat depth. At $90 \mathrm{~kg}$ most of the ultrasonic measurements indicated skin plus fat depths in excess of one $\mathrm{cm}$.

As animals become fatter the chemical composition of the adipose tissue changes. Adipose tissue from fatter animals contains more lipid and less water and protein (LUSH, 1926; CALLOW, 1948; ENDER et al., 1997). ABERLE et al. (1977) reported a correlation coefficient of 0.85 for Log \% lipid in ham and \% lipid in the adipose tissue (data from 25 carcasses weighing between 68 and $82 \mathrm{~kg}$ ). A similar correlation coefficient (0.84) was observed for Log \% whole carcass lipid and \% lipid in adipose tissue taken from the backfat of pigs (359 carcasses weighing between 6 and $65 \mathrm{~kg}$, see Figure 4). In addition, calculations based on the data presented by Warriss et al gives a correlation coefficient of -0.95 for the log decrease in water content (mg of water/g of fat) relative to backfat thickness $(\mathrm{mm})$ for pigs slaughtered at an average live weight of $62 \mathrm{~kg}$. Even at fat depths of less than one $\mathrm{cm}$, the signal from lipids in the skin and adipose tissue could be a major contributor to the NIR interactance readings obtained in the present study. Thus, it is possible that the sensor was detecting primarily 
changes in the lipid content of the subcutaneous fat or adipose tissue. If this was the case, then the relationship between the percent lipid in the adipose tissue and the fat content of the whole carcass may present a theoretical limit to the ability of NIR to predict the fat content of pigs

From the above results and discussion it appears that with the current technology the primary limitations to this technique are: (1) the ability to probe to sufficient depth with adequate sensitivity and (2) determination of the best site or combination of sites which will be representative of whole body composition. A possible improvement in the technique might involve the use of laser diodes to increase the depth of penetration and focusing of the near infra-red energy. If the optimal use of NIR for predicting body composition involves the relationship between adipose tissue composition and body fatness, then it is likely that the backfat would be a better site to monitor. Also, it may be that some additional measure of body size, dimension or conformation would be beneficial.

It may be that this approach for using near-infrared interactance to estimate the composition of the live pig or carcass may not prove accurate enough as a stand alone technique. However, it's use as a surface probe may provide additional information that could be used in conjunction with other techniques such ultrasound probe or imaging and thereby enhance the ability to predict carcass composition.

\section{Acknowledgements}

The authors express their appreciation to K. H. Norris, H. H. Klueter, and N. Faulkner for their technical assistance.

\section{References}

ABERLE, E.D.; ETHERTON, T.D.; ALLEN, C.E.:

Prediction of pork carcass composition using subcutaneous adipose tissue moisture or lipid concentration. J. Anim. Sci. 45 (1977), 449-456

AOAC:

Official Methods of Analysis (14th Ed.). Association of Official Analytical Chemists, Washington, DC (1984)

BRØNDUM, J.; MUNCK, L.; HENCKEL, P.; KARLSSON, A.; TORNBERG, E; ENGELSEN, S.B.:

Prediction of waterholding capacity and composition of porcine meat by comparative spectroscopy. Meat Sci. 55 (2000), 177-185

BYRNE, C.E.; DOWNEY, G.; TROY, D.J.; BUCKLEY, D.J.:

Non-destructive prediction of selected quality attributes of beef by near-infrared reflectance spectroscopy between 750 and $1098 \mathrm{~nm}$. Meat Sci. 49 (1998), 399-409

CONWAY, J.M.; NORRIS, K.H.; BODWELL, C.E.:

A new approach for the estimation of body composition: infrared interactance. Am. J. Clin. Nutr. 40 (1984), 1123-1130

CALLOW, E.H.:

Comparative studies of meat; the changes in the carcass during growth and fattening and their relation to the chemical composition of the fatty and muscular tissues. J. Agr. Sci. 38 (1948), 174

EATON, A.W.; ISRAEL, R.G.; O'BRIEN, K.F.; HORTOBAGYI, T.; MCCAMMON, M.R.:

Comparison of four methods to assess body composition in women. Eur. J. Clin. Nutr. 47 (1993), 353360

EISEN, E.J.; BANDY, T.R.; MCCLURE, W.F.; HORSTGEN-SCHWARK, G.:

Estimating body composition in mice by near-infrared spectrophotometry. J. Anim. Sci. 58 (1984), 1181-1190

ELIA, M.; PARKINSON, S.A.; DIAZ, E.:

Evaluation of near infrared interactance as a method for predicting body composition. Eur. J. Clin. Nutr. 44 (1990), 113-121 
ENDER, K.; NÜRNBERG, K.; PAPSTEIN, H.-J.:

Die zwei Seiten des Fettes - eine Standortbestimmung. Arch. Tierz., Dummerstorf 40 (1997), 35-45

FOLCH, J.; LEES, M.; SLOANE STANLEY, G.H.:

A simple method for the isolation and purification of total lipids from animal tissue. J. Biol. Chem. 226 (1957), 497-509

FRANSILLA-KALLUNKI, A.:

Comparison of near-infrared light spectroscopy, bioelectrical impedance and tritiated water techniques for the measurement of fat -free mass in humans. Scand. J. Clin. Lab. Invest. 52 (1992), 879-885

GEESINK, G.H.; SCHREUTELKAMP, F.H.; FRANKHUIZEN, R.; VEDDER, H.W.; FABER, N.M.;

KRANEN, R.W.; GERRITZEN, M.A.:

Prediction of pork quality attributes from near infrared reflectance spectra. Meat Sci. 65 (2003), 661668

GONZÁLEZ-MARTÍN, I.; GONZÁLEZ-PÉREZ, C.; ALVAREZ-GARCÍA, N.; GONZÁLEZ-CABRERA, J.M.:

On-line determination of fatty acid composition in intramuscular fat of Iberian pork loin by NIRs with a remote reflectance fibre optic probe. Meat Sci. 69 (2005) 243-248.

HADDOCK, B.L.; TAN, S.A.; BERK, L.S.:

Body composition assessment with near infrared interactance. Med. Sci. Sports Exerc. 22 (1990), S111

HEYWARD, V.H.; COOK, K.L.; HICKS, V.L.; JENKINS, K.A.; QUATROCHI, J.A.; WILSON, W.L.:

Predictive accuracy of three field methods for estimating relative body fatness of nonobese and obese women. Int. J. Sports Nutr. 2 (1992), 75-86

HORTOBAGYI, T.; ISRAEL, R.G.; HOUMARD, J.A.; MCCAMMON, M.R.; O'BRIEN, K.F.:

Comparison of body composition assessment by hydrodensitometry, skinfolds, and multiple site nearinfrared spectrophotometry. Eur. J. Clin. Nutr. 46 (1991), 205-211

HOVING-BOLINK, A.H.; VEDDER, H.W.; MERKS, J.W.M.; DE KLEIN, W.J.H.; REIMERT, H.G.M.;

FRANKHUIZEN, R.; VAN DEN BROEK, W.H.A.M.; LAMBOOIJ, EN E.:

Perspective of NIRS measurements early post mortem for prediction of pork quality. Meat Sci. 69 (2005), 417-423

IRIE, M.:

Evaluation of porcine fat with fiber-optic spectroscopy. J. Anim. Sci. 77 (1999), 2680-2683

ISRAEL, R.G.; HOUMARD, J.A.; O'BRIEN, K.F.; MCCAMMON, M.R.; ZAMORA, B.S.; EATON, A.W.:

Validity of a near-infrared spectrophotometry device for estimating human body composition. Res. Q. Exerc. Sport 60 (1989), 379-383

KLIMIS-TAVANTZIS, D.; OULARE, M.; LEHNHARD, H.; COOK, R.A.:

Near infrared interactance: validity and use in estimating body composition in adolescents. Nutr. Res. 12 (1992), 427-439

KRUGGEL, W.G.; FIELD, R.A.; RILEY, M.L.; RADLOFF, H.D.; HORTON, K.M.:

Near-infrared reflectance determination of fat, protein and moisture in fresh meat. J. Assoc. Off. Anal. Chem. 64 (1981), 692-696

LANZA, E.:

Determination of moisture, protein, fat, and calories in raw pork and beef by near infrared spectroscopy.

J. Food Sci. 48 (1983), 471-474

LUSH, J.L.:

Practical methods for estimating the proportions of fat and bone in cattle slaughtered in commercial packing plants. J. Agr. Res. 32 (1926), 727

MCLEAN. K.P.; SKINNER, J.S.:

Validity of Futrex-5000 for body composition determination. Med. Sci. Sports Exerc. 24 (1992), 253258

MITCHELL, A.D.; STEELE, N.C.:

Comparison of urea space, deuterium oxide space and body composition in growing pigs. Growth $\mathbf{5 1}$ (1987), 118-131

NIELSEN, D.H.; CASSADY, S.L.; WACKER, L.M.; WESSELS, A.K.; WHEELOCK, B.J.; OPPLIGER, R.A.: Validation of the Futrex-5000 near-infrared spectrophotometer analyzer for assessment of body composition. J. Orthop. Sports Phys. Ther. 16 (1992), 281-287

NORRIS, K.H.:

Instrumental techniques for measuring quality of agricultural crops. In: M. Lieberman (Ed.) Postharvest physiology and crop preservation. pp 84. Plenum Publishing Corp., NY (1983)

NORRIS, K.H.; BARNES, R.F.; MOORE, J.E.; SHENK, J.S.: Predicting forage quality by infrared reflectance spectroscopy. J. Anim. Sci. 43 (1976), 889-897

PARK, B.; CHEN, Y.R.; HRUSCHKA,W.R.; SHACKELFORD, S.D.; KOOHMARAIE, M.: Near-infrared reflectance analysis for predicting beef longissimus tenderness. J. Anim. Sci. 76 (1998), 2115-2120 
QUATROCHI, J.A.; HICKS, B.L.; HEYWARD, V.H.; COLVILLE, B.C.; COOK, K.L.; JENKINS, K.A.; WILSON, W.L.:

Relationship of optical density and skinfold measurements: effects of age and level of body fatness. Res. Quart. Exerc. Sport 63 (1992), 402-409

RENDEN. J.A.; OATES, S.S.; REED, R.B.:

Determination of body fat and moisture in dwarf hens with near-infrared reflectance spectroscopy. Poultry Sci. 65 (1986), 1539-1541

RØDBOTTEN, R.; NILSEN, B.N.; HILDRUM, K.I.:

Prediction of beef quality attributes from early post mortem near infrared reflectance spectra. Food. Chem. 69 (2000), 427-436

SHACKELFORD, S.D.; WHEELER, T.L.; KOOHMARAIE, M.:

On-line classification of US Select beef carcasses for longissimus tenderness using visible and nearinfrared reflectance spectroscopy. Meat Sci. 69 (2005), 409-415

SHIMAMOTO, J.; HASEGAWA, K.; SATO, M.; KAWANO, S.:

Non-destructive determination of fat content in frozen and thawed mackerel by near infrared spectroscopy. Fisheries Sci. 70 (2004), 345-347

SLAUGHTER, D.C.; KLUETER, H.H.; MITCHELL, A.D.; NORRIS, K.H.:

Near infrared reflectance of ground hog carcass composition. Proceedings, Second Intl. NIR Spectra Conf., Osaka, Japan (1989)

WARRISS, P.D.; BROWN, S.N.; FRANKLIN, J.G.; KETSIN S.C.:

The Thickness and Quality of Backfat in Various Pig Breeds and Their Relationship to Intramuscular Fat and the Setting of Joints from the Carcasses. Meat Sci. 28 (1990), 21-29

WILMORE, K.M.; MCBRIDE, P.J.; WILMORE, J.H.:

Comparison of bioelectric impedance and near-infrared interactance for body composition assessment in a population of self-perceived overweight adults. Intl. J. Obesity 18 (1994), 375-381

WILSON, W.L.; HEYWARD, V.H.:

Validation of the near-infrared interactance method for black, hispanic, native american and white men 20 to 50 years. Proceedings: Int. Symp. In Vivo Body Comp. Studies, Abstract \# 79 (1992)

Received: 2005-04-04

Accepted: 2005-10-25

Author's addresses

Dr. ALVA D. MITCHELL, PhD.

United States Department of Agriculture

Growth Biology Laboratory

BELTSVILLE, MD 20705, USA

E-Mail: mitchell@anri.barc.usda.gov

PD Dr. ARMIN M. SCHOLZ

Lehr- und Versuchsgut der Tierärztlichen Fakultät der

Ludwig-Maximilians-Universität München

Hubertusstr. 12

85764 OBERSCHLEIßHEIM

GERMANY

Dr. MORSE B. SOLOMON, PhD.

United States Department of Agriculture

Food Technology and Safety Laboratory

BELTSVILLE, MD 20705, USA 